\title{
Allelopathic Performance of Medicinal Plants on Traditional Oilseed and Pulse Crop of Central Himalaya, India
}

\author{
${\text { Lakhpat Singh } \text { Rawat }^{1} \cdot \text { R. K. Maikhuri }}^{1} \cdot$ Vikram S. Negi $^{1} \cdot$ Yateesh M. Bahuguna $^{1}$ • \\ Dalbeer S. Pharswan ${ }^{1} \cdot$ Ajay Maletha ${ }^{1}$
}

Received: 31 October 2013/Revised: 17 February 2015/Accepted: 9 February 2016/Published online: 22 March 2016

(C) The Author(s) 2016. This article is published with open access at Springerlink.com

\begin{abstract}
The present study was aimed to determine the allelopathic effect of aqueous extract of above ground (AG) and below ground (BG) part of four medicinal plants (MAPs) viz., Picrorhiza kurroa, Asperagus racemosus, Ocimum sanctum and Valeriana wallichii on germination and seedling growth of some traditional food and oilseed crops. The aqueous extract of AG and BG part of the studied MAPs at $2 \%$ significantly reduced the germination, plumule and radicle growth of the selected pulse and oil seed crops in bioassays. The results of the present experiments revealed that MAPs have inhibitory effect on food and oilseed crops owing an occurrence of allelochemicals.
\end{abstract}

Keywords Medicinal plants · Allelopathy .

Aqueous extract · Oilseed crops · Pulses

Indian Himalaya has been recognized rich in medicinal and aromatic plants [MAPs] [1]. However, as a result of anthropogenic activity to collect the MAPs illegally and legally from natural habitat, the population of MAPs decreased at an alarming rate and rendered them under threat, vulnerable, extinct and endangered category $[2,3]$. Hence, to maintain long term sustainability and conservation of this wild wealth, domesticated cultivation is obviously an alternate option [4]. Though, indigenous communities in mountain Himalaya are accustomed to cultivate a variety of food crops, cereales, oilseed crops,

Lakhpat Singh Rawat

rawat_lakhpat@rediffmail.com

1 Garhwal Unit, G.B. Pant Institute of Himalayan Environment and Development, Srinagar Garhwal, Uttarakhand, India millets and certain cash crops in settled terraced agriculture fields. However, low agricultural productivity coupled with lack of appropriate technologies to enhance the crops yield has enforced mountain people to adopt new and profitable venture like cultivation of medicinal plants. Allelopathy is an important interference mechanism wherein one plant releases bioactive chemicals into the surrounding environment that affect the growth of other plants [5]. These chemicals are largely classified as secondary plant metabolites (such as alkaloids, isoprenoids, phenolics, flavonoids, terpanoids and gluconolates etc.). Allelochemicals are present in virtually all plant tissues, including leaves, flowers, fruits, stems, roots, rhizomes, seeds and pollen. The phytotoxic effects of substances released by leaching, root exudation and residue decomposition of certain plants on germination and seedling growth of the associated plants have been amply demonstrated [6-9]. However, none of the study is known on the allelopathic behaviour of medicinal plants on germination and seedling growth of the traditional oil seed and pulse crops from Indian Himalayan region. Keeping in view the paucity of data on allelopathic influence of medicinal plants on traditional crops, the present study was initiated with the objectives to determine the effect of few plant species of MAPs that are being cultivated by the farmers viz., Picrorhiza kurroa, Asperagus racemosus, Ocimum sanctum and Valeriana wallichii on germination and growth of some important traditional oilseeds and pulse crops to understand the allelopathic behavior of medicinal plants on food and oil seed crops in a multi-cropping system.

Fresh, mature plants (leaves, stem, rhizome, roots) of selected MAPs were collected at flowering stage from naturally growing population of Tungnath, north-west Himalaya India. Sun dried AG and BG parts of studied 
MAPs were grounded and $2.0 \mathrm{~g}$ powdered sample of each species was added to $100 \mathrm{ml}$-distilled water to prepare $2 \%$ aqueous extract and left for $48 \mathrm{~h}$ at room temperature $\left(20-30{ }^{\circ} \mathrm{C}\right)[10]$. The extract was then filtered through two layers of cheese cloth and centrifuged for $20 \mathrm{~min}$ at $15,000 \mathrm{rpm}$ using a SOVAL centrifuge. This extract concentration $(2 \mathrm{~g} / 100 \mathrm{ml})$ was considered for future comparisons as the undiluted extract (i.e. $100 \%$ ) [11, 12]. All procedures following centrifugation of the extract were carried out in a cross-flow laminar flow cabinet to minimize contamination. Seeds of test species viz., Sesamum indicum, Vigna angularis, Glycine max, Vigna mungo, Perilla frutescense and Echinochloa frumentacea were surface sterilized with $2 \% \mathrm{NaClO}$ for $1 \mathrm{~min}$ and rinsed seven times with sterile distilled water. 25 Seeds of each species were then placed in $9 \mathrm{~cm}$ petri plates lined with filter papers (Whatman \#1) which were saturated with $5.0 \mathrm{ml}$ extract respective leachate of each plant. A separate control series was set up using distilled water. The plates were placed in an incubator with a $14 \mathrm{~h}$ day/10 h night cycle for 8 days. Moisture in the petri dishes was maintained by adding about $1.0 \mathrm{ml}$ of leachate or distilled water as required. Seed germination was counted after 4 days of sowing (DAS) while radicle growth and plumule length was recorded after 8 days of sowing [13, 14]. Three replicates were arranged in a randomized complete block design under the experimental conditions mentioned above. The data were analyzed statistically using ANOVA.

The aqueous extract of BG part of Asperagus racemosus reduced maximum $(46 \%)$ germination percentage of Perilla frutescense (Fig. 1). The AG part of Picrorhiza kurroa reduced drastically the germination of all crops between the range of $12-44 \%$. Similarly, the BG part of Asperagus racemosus was observed to be maximum harmful to germination of all tested crops in which the reduction percentage was between 14 and $46 \%$ (Fig. 1). However, Echinochloa frumentacea was affected least (8-14 \%) under both AG and BG part of all four medicinal plants (Fig. 1). The germination percentage of all oil and pulse crops were inhibited drastically by the aqueous extract of studied medicinal plants in general but Perilla frutescense was observed to be most vulnerable against $\mathrm{AG}$ part (Fig. 1). These findings also confirm that extracts of many plant species including medicinal herbs contain allelochemicals which have been reported to affect enzyme responsible for plant hormone synthesis, in addition to inhibition of nutrient and ion absorption by affecting plasma membrane permeability [15]. As far as assessment of reduction percent in plumule and radicle length was concerned, maximum reduction $(64.20 \%$ in plumule and $65.78 \%$ in radicle length) was found in Perilla frutescense under $2 \%$ aqueous extract of AG part of Ocimum sanctum (Table 1). However, Sesamum indicum was affected least with only 11.05 and $9.81 \%$ reduction in plumule and radicle length respectively, under AG part of Asperagus racemosus compared to other species over control (Table 1). Effect of a given compound or plant metabolites might be inhibitory or stimulatory depending on their concentration in the surrounding medium [16]. This differential sensitivity has been observed in the field, green house and laboratory experiments with residues, extracts and purified allelochemicals [17]. The present study definitely suggests that the addition of aqueous extract of these four medicinal species strongly affected the germination
Fig. 1 Effect of $2 \%$ aqueous extract above ground (AG) and belowground (BG) parts of medicinal plant on germination of traditional oil seed and pulses after 10 days of sowing
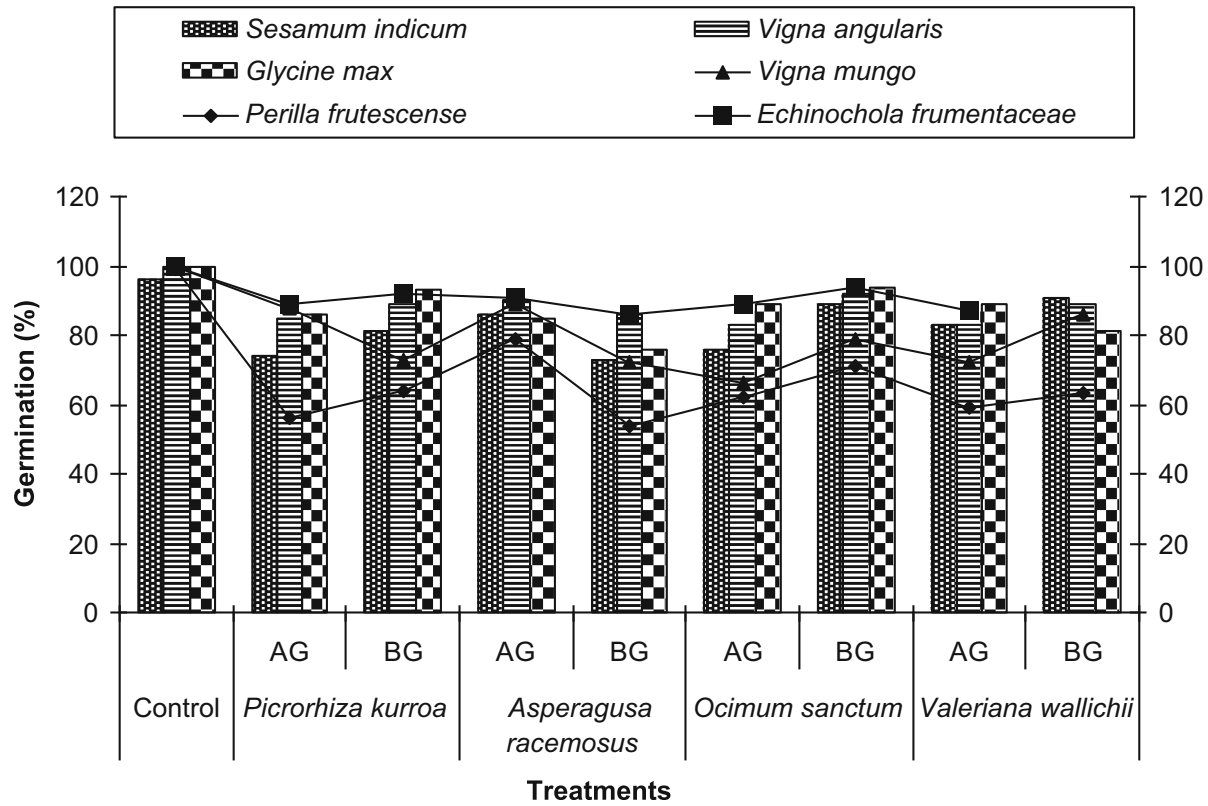
efficiency and growth characters of all oilseed and pulse crops when compared to the control. Similarly, Darier and Youssef [18] also reported the inhibitory effect of aqueous extract of alfalfa on germination and seedling growth of Lepidium sativum. These results are in agreement with the results of Stachon and Zimdel [19] which reported that the extracts of allelopathic plants had more inhibitory effect on root growth than on hypocotyl growth because root is the first organ to absorb allelochemical from the environment. Similar kinds of results were reported from the studies of Chon et al. [20] in which root length was the best indicator of allelopathic effects of plant extract because root growth has been reported to be more sensitive to phytotoxic compounds than hypocotyl growth in alfalfa.

Based on the results of the present study it could be suggested that the four medicinal plants species can be grown satisfactorily under traditional agriculture systems of subtropical-sub temperate region if whole plants of these medicinal species are harvested from the agricultural fields and nothing is left in the fields for allelopathic influence. Domesticated cultivation of medicinal plants is clearly a sustainable alternative in order to preserve this wild wealth and increase the farm income of local farmers but not at the cost of degradation of the yield of traditional crops. The farming communities inhibiting in mountain Himalaya are required to be made aware about the influence of MAPs on crops and appropriate way of cultivation of MAPs should be developed so that the twin objectives of increasing the farm income and conservation of the resources could be achieved.

Acknowledgments The authors are grateful to the Director of the Institute for providing facilities and NAIP, ICAR and SERB, DST New Delhi for financial support.

Open Access This article is distributed under the terms of the Creative Commons Attribution 4.0 International License (http:// creativecommons.org/licenses/by/4.0/), which permits unrestricted use, distribution, and reproduction in any medium, provided you give appropriate credit to the original author(s) and the source, provide a link to the Creative Commons license, and indicate if changes were made.

\section{References}

1. Hill AF (1952) Economic botany. McGrow-Hill Book Company, Encyclopedia, Tokyo

2. Maikhuri RK, Rao KS, Kandari LS, Joshi R, Dhyani D (2005) Does the outreach programme makes an impact? A case study of medicinal and aromatic plant cultivation in Uttaranchal. Curr Sci 88:1480-1486

3. Dhar U, Manjkhola S, Joshi M (2002) Current status and future strategy for development of medicinal plant sector in Uttaranchal, India. Curr Sci 83:956-964

4. Rawat RBS (2003) National medicinal plants board (introduction and schemes). Indian For 129:109-118 
5. Rice EL (1984) Allelopathy, II edn. Academic Press, London, $\mathrm{p} 422$

6. Bhatt BP, Chauhan DS, Todaria NP (1994) Effect of weed leachates on germination and radicle extension of some food crops. Indian J Plant Physiol 37:177-179

7. Kaletha MS, Bhatt BP, Todaria NP (1996) Allelopathic cropweed interactions in traditional agroforestry systems of Garhwal Himalaya. Allelopath J 3:65-70

8. Tripathi S, Tripathi A, Kori DC, Tiwari S (1998) Effect of tree leaf aqueous extract on germination and seedling growth of soybean. Allelopath J 5:75-82

9. Bhatt BP, Chauhan DS (2000) Allelopathic effects of Quercus spp. on crops of Garhwal Himalaya. Allelopath J 7:265-272

10. Nazir T, Uniyal AK, Todaria NP (2007) Allelopathic behaviour of three medicinal plant species on traditional agriculture crops of Garhwal Himalaya, India. Agrofor Syst 69:183-187

11. Rawat LS (2002) Herbicidal potential of sunflower. Ph. D. thesis submitted to H N B Garhwal University Srinagar Garhwal Uttarakhand, India

12. Rawat LS, Maikhuri RK, Negi VS (2013) Inhibitory effect of leachate from Helianthus annuus on germination and growth of kharif crops and weeds. Acta Ecol Sin 33:245-252
13. Rawat LS, Narwal SS, Kadian HS, Negi VS (2011) Allelopathic effect of sunflower on germination and growth of Parthenium hysterophorus. Allelopath J 27(2):225-236

14. Rawat LS, Narwal SS, Kadian HS, Negi VS, Maikhuri RK, Pharswan D (2012) Allelopathic effect of sunflower on germination and seedling growth of Trianthema portulacastrum. Allelopath J 30(1):11-22

15. Fujii Y, Furukawa M, Hayakawa Y, Sugahara K, Shibuya T (1991) Survey of Japanies medicinal plants for the detection of allelopathic properties. Weed Res Tokyo 36:36-42

16. Khailov KM (1974) Biochemical traphodynamics in marine coastal ecosystems. USSR, Naukova Dumka, Kiev

17. Leslie AW (1996) Utilization of allelopathy for weed management in agroecosystems. Agron J 88:860-866

18. Darier SMEL, Youssef RS (2000) Effect of soil type, salinity and allelochemicals on germination and seedling growth of a medicinal plant Lepidium sativum L. Assoc Appl Biol 136:273-279

19. Stachon WJ, Zimdel RL (1980) Allelopathic activity of Canada thistle Cirsium arvense in Colorado. Weed Sci 28:83-86

20. Chon SU, Coutts JH, Nelson CJ (2000) Effects of light, growth media and seedling orientation on bioassays of alfalfa autotoxicity. Agron J 92:715-720 